\title{
Untreated Childhood Gliosarcoma
}

National Cancer Institute

\section{Source}

National Cancer Institute. Untreated Childhood Gliosarcoma. NCI Thesaurus. Code C115946.

A finding of gliosarcoma in childhood that has not been treated. 